\title{
Molecular characterization of potato cultivars using SSR markers
}

\author{
Patrícia Favoretto $^{1}$; Elizabeth Ann Veasey ${ }^{2}$; Paulo César Tavares de Melo ${ }^{1}$ \\ USP-ESALQ, ${ }^{2}$ Dep ${ }^{\text {to }}$ Produção Vegetal; ${ }^{2}$ Dep ${ }^{\text {to }}$ Genética, C. Postal 9, 13418-900, Piracicaba-SP; pafavo@esalq.usp
}

\begin{abstract}
The potato crop has a very narrow genetic base, so the use of molecular markers is a very important tool in the characterization of germplasm banks and evaluation of genetic divergence. The objective of this study was to identify, using microsatellite or simple sequence repeat (SSR) markers, 38 accessions of potato from two collections of commercial cultivars. For the molecular characterization 10 loci were used, generating a total of 46 alleles, which were analyzed as binary data. A cluster analysis was performed with the Jaccard's similarity coefficient and the UPGMA method, using the software NTSYSpc. On average, the number of alleles per locus was 4.6, ranging from two alleles for primers STM1049, STM 1053 and STM 1104 to 12 alleles per locus for primer STM0019a. Of the 46 alleles, only five were monomorphic, therefore presenting $89.1 \%$ polymorphism. The polymorphism information content (PIC) varied from 0.13 to 0.86 , with an average of 0.54 . The Jaccard's coefficient varied from 0.41 to 0.93 , showing high genetic variability among accessions. Two possible duplicates [Atlantic (Canada) and Atlantic (Chile), and Colorado and Ágata (EPAMIG) (duplicates with these SSRs, which did not separate them)] were identified. High similarity was also shown by cultivars Chipie and Melodie (EPAMIG), Voyager and Gourmandine (EPAMIG), Eole and Caesar (EPAMIG), and Cupido and Santé (Pirassu). The most genetically divergent accessions (Lady Rosetta and HPC-7B) were also identified.
\end{abstract}

Keywords: Solanum tuberosum, germplasm banks, genetic diversity, microsatellites.

\section{RESUMO}

Caracterização molecular de cultivares de batata por marcadores SSR

A batata possui uma base genética estreita, sendo assim a utilização de marcadores moleculares é uma ferramenta muito importante no processo de caracterização de bancos de germoplasma e avaliação de divergência genética. $\mathrm{O}$ objetivo deste trabalho foi avaliar por meio de marcadores microssatélites ou Simple Sequence Repeats (SSR), 38 acessos de batata de duas coleções distintas contendo cultivares comerciais. Para a caracterização molecular foram analisados 10 loci, gerando um total de 46 alelos, os quais foram analisados como dados binários. Foi obtida uma matriz de similaridade utilizando o coeficiente de Jaccard e com o método aglomerativo UPGMA foi realizada uma análise de agrupamento pelo software NTSYSpc. Em média, o número de alelos por loco foi 4,6, variando de dois alelos para os iniciadores STM1049, STM1053 e STM1104 até 12 alelos por loco para o iniciador STM0019a. Dos 46 alelos identificados, apenas cinco foram monomórficos, observando-se, portanto, $89,1 \%$ de polimorfismo. O conteúdo de informação de polimorfismo (PIC) variou de 0,13 a 0,86 , com média de 0,54 . O coeficiente de similaridade de Jaccard variou de 0,41 a 0,93 , mostrando a grande variabilidade genética entre os acessos. Observaram-se duas possíveis duplicatas [Atlantic (Canadá) e Atlantic (Chile), e Colorado e Ágata (EPAMIG) (duplicatas com estes SSRs, que não as separaram)]. Elevada similaridade foi também observada pelas cultivares Chipie e Melodie (EPAMIG), Voyager e Gourmandine (EPAMIG), Eole e Caesar (EPAMIG), e Cupido e Santé (Pirassu). Foram identificados também os acessos mais distantes geneticamente (Lady Rosetta e HPC-7B).

Palavras-chave: Solanum tuberosum, bancos de germoplasma, diversidade genética, microssatélites.

(Recebido para publicação em 26 de julho de 2010; aceito em 28 de novembro de 2011) (Received on July 26, 2010; accepted on November 28, 2011)

$\mathrm{P}$ tato (Solanum tuberosum L.), in order of economic importance, is the fourth most important food crop in the world, after wheat, rice and maize, with a global annual production of approximately 300 million tones (CIP, 2011). Worldwide, this crop is undergoing major changes. Until the beginning of 1990, it was the most cultivated and consumed in Europe, North America and in countries of the former Soviet Union. Since then, there has been an increase in potato production and demand in Asia, Africa and Latin America (FAO, 2008). Brazil ranks as a major potato producer in Latin America, with a record harvest in
2006 of around 33.1 million tons. Over the past 15 years, potato production increased, on average, $5 \%$ a year and, the average yield increased from 14 to 22 tons per hectare. Current data indicate a total area of 138,852 ha and a total production of $3,438,825$ tons with an average yield of 24.7 tons per ha, showing a positive variation of $3.7 \%$ (IBGE, 2009; AGRIANUAL, 2009).

Despite the great progress in all these years, it is necessary to search for more productive, adapted and resistant material. Molecular characterization is an important biotechnology tool in plant breeding programs. Microsatellites, also called SSR (Simple Sequence Repeats), are one of the more polymorphic molecular markers available today (Ferreira \& Grattapaglia, 1998). Microsatellites also have advantages over other markers based on PCR (Polymerase Chain Reaction), such as RAPD (Random Amplified Polymorphic DNA), because they are co-dominant and easily reproducible, and have a frequent and random distribution, allowing a wide coverage of the genome. The high level of variation detected with microsatellites increases the resolution for genealogy and germplasm genetic diversity studies and reduces the number of markers required to distinguish between genotypes (Borém \& Caixeta, 
2006).

Rocha (2008), using six RAPD and three SSR primers, identified 16 cultivars of potato. The author observed that SSR markers were more efficient than RAPD markers, since three of the SSR primers allowed the distinction of all cultivars studied, compared with the six primers used for RAPD. Several studies have used SSR markers for the characterization of potato cultivars and accessions, such as Norero et al. (2002), Braun \& Wenzel (2004), Braun et al. (2004), Chimote et al. (2004), Ghislain et al. (2006), Barandalla et al. (2006), Mathias et al. (2007), Ispizúa et al. (2007), and Fu et al. (2009). These last authors evaluated 114 Canadian and 55 exotic potato accessions using 36 SSR loci. However, except for the study conducted by Rocha (2008), no studies have yet been found in Brazil using SSR markers to identify potato cultivars. Within this context, the aim of this study was to characterize, at the molecular level using microsatellite markers, 38 commercial cultivars of potatoes from two collections.

\section{MATERIAL AND METHODS}

Thirty-eight potato cultivars from two collections, Pirassu Company, located in Vargem Grande do Sul, São Paulo state, Brazil, and Empresa de Pesquisa Agropecuária de Minas Gerais (EPAMIG), were assessed. Details of the source and country of origin, including the genealogy of each cultivar are described (Table 1).

For the DNA extraction, recently expanded leaves were dried in an oven at $45^{\circ} \mathrm{C}$ for a period of 24 hours, after which they were macerated and submitted to a 3\% CTAB methodology, as described by Siqueira et al. (2009). DNA concentration of each genotype was estimated by running samples in $0.8 \%$ agarose gels. The gels were prepared in advance, using $0.8 \mathrm{~g}$ of agarose diluted in $1 \mathrm{X}$ TBE buffer [100 $\mathrm{mL} 10 \mathrm{X}$ TBE $(0.89 \mathrm{M}$ Tris base, 0.89 $\mathrm{M}$ boric acid, 20mM EDTA pH 8.0) and $900 \mathrm{~mL}$ of distilled water] and stained with $4 \mu \mathrm{L}$ Ethidium bromide. DNA concentration was estimated by comparison to standard undigested lambda DNA, with a range variation of $10,20,50,80$ and $100 \mathrm{ng}$.

Ten potato specific microsatellite primers were used (Ghislain et al., 2006) (Table 2). Polymerase chain reactions (PCR) were performed in 10.2 $\mu \mathrm{L}$ volume containing approximately $15 \mathrm{ng}$ of template DNA, $5 \mathrm{U}$ of Taq DNA Polymerase, $50 \mathrm{mM} \mathrm{MgCl}, 1 \mathrm{x}$ Polymerase Buffer, 5 pmoles of each forward and reverse primers, and 2,5 $\mathrm{mM}$ of dNTPs mix. For these reactions, the thermocycler MyCycler Thermal Cycler model of BioRad was used. PCR reactions were conducted in the following sequence: $3 \mathrm{~min}$ at $94^{\circ} \mathrm{C}$, followed by 30 cycles of $30 \mathrm{sec}$ at $94^{\circ} \mathrm{C}$, $1 \mathrm{~min}$ at the annealing temperature for each primer set (Table 2) and $1 \mathrm{~min}$ at $72^{\circ} \mathrm{C}$, and the final extension of $5 \mathrm{~min}$ at $72^{\circ} \mathrm{C}$.

The amplification products were separated in $6 \%$ polyacrylamide gels under an initial voltage of 60 volts for 30 min, extending it to 120 volts for about $2 \mathrm{~h}$ in TBE buffer (0.09 M Tris, 0.09 $\mathrm{M}$ boric acid, $2 \mathrm{mM}$ EDTA). Standard molecular weight markers of $10 \mathrm{bp}$ and $100 \mathrm{bp}$ were used. The material was stained with silver nitrate (Bassam et al., 1991) to reveal the microsatellite bands, which were analyzed in a transilluminator and photodocumented using a digital camera.

For the statistical analysis, each SSR locus was characterized as a dominant marker, according to the presence or absence of bands, which were analyzed visually. These data were used in the construction of a binary data matrix, where the value 1 (one) means presence of bands and the value 0 (zero) their absence. With this matrix, the Jaccard similarity coefficients were obtained. Using this coefficient and the cluster method UPGMA (Unweighted pairgroup method with arithmetic averages), a cluster analysis was performed using the NTSYSpc (Numerical Taxonomy and Multivariate Analysis System) software (Rohlf, 1992). NTSYSpc was used also to estimate the cophenetic value. The accuracy of the groupings was estimated from simulations with resampling, using 10,000 bootstraps, and the BOOD software, version 2.0
(Coelho, 2001). The polymorphism information content (PIC) was calculated by the formula: $P I C=1-\sum_{i=1}^{n} p_{i}^{2} \quad$ where: $\mathrm{pi}=$ frequency of the allele (band) in each locus and $n=$ number of alleles observed.

\section{RESULTS AND DISCUSSION}

All 10 loci used in this study showed polymorphism among the accessions analyzed, producing well-defined and reproducible bands. A total of 46 alleles were amplified with an average of 4.6 alleles per locus, ranging from two alleles for primers STM1049, STM1053 and STM1104 to 12 for the primer STM0019a (Table 2). Only five alleles were present in all the varieties evaluated, while 41 alleles were shown to be polymorphic for all the 38 cultivars, therefore showing $89.1 \%$ polymorphism. Milbourne et al. (1997), evaluating 14 potato genotypes from northwestern Europe with 17 SSR loci, found 98 alleles (bands) with an average of 5.76 alleles, greater than the value reported in this study, although with a greater number of loci. Braun \& Wenzel (2004), evaluating 69 cultivars from Germany with 26 SSR loci, observed 128 alleles ( $98.4 \%$ polymorphism) and a mean number of alleles of 5.12. Mathias et al. (2007) observed a variation of two to 17 alleles/locus in the evaluation of 71 genotypes from INIA, Chile, with 21 SSR loci, in agreement with $\mathrm{Fu}$ et al. (2009) reporting two to 17 alleles per locus in the evaluation of 114 Canadians and 55 exotic potato accessions with 36 SSR loci. The values found in this study, ranging from two to 12 alleles/locus, are therefore consistent with the literature whereas a smaller number of genotypes (38) was evaluated.

The polymorphism information content (PIC) ranged from 0.13 to 0.86 , averaging 0.54 , with the highest value obtained for primer STM0019a and the lowest value obtained for primer STM1053, showing that the SSR primers in this study presented, on average, a high level of information. Similar values were obtained by Rocha (2008), with PIC values ranging from 0.21 to 0.97 in the evaluation of 16 
Table 1. List of the accessions of potato (Solanum tuberosum) studied, including their source ${ }^{1}$, crossings $^{2}$ and origin (lista dos acessos de batata (Solanum tuberosum) estudados, incluindo a fonte de obtenção, sua genealogia e origem). Piracicaba, USP-ESALQ, 2009.

\begin{tabular}{|c|c|c|c|c|}
\hline $\mathbf{N}^{0}$ & Varieties & Source & Crossings & Origin \\
\hline 1 & AGATA & Pirassu & BM 52/72/2206 X Sirco & HOL \\
\hline 2 & AGATA & EPAMIG & BM 52/72/2206 X Sirco & HOL \\
\hline 3 & ASTERIX & Pirassu & ‘Cardinal’ x ‘VE 70-9' & HOL \\
\hline 4 & ASTERIX & EPAMIG & 'Cardinal' x 'VE 70-9' & HOL \\
\hline 5 & ATLANTIC & Pirassu & Wauseon x B 5141-6 (Lenape) & USA \\
\hline 6 & ATLANTIC & Pirassu & Wauseon x B 5141-6 (Lenape) & USA \\
\hline 7 & ATLANTIC & EPAMIG & Wauseon x B 5141-6 (Lenape) & USA \\
\hline 8 & BRS ANA & EPAMIG & 'C-1750-15-95’x 'Asterix’ & BRA \\
\hline 9 & BRS ELIZA & EPAMIG & 'Edzina'x 'Recent' & BRA \\
\hline 10 & CAESAR & EPAMIG & 'Monalisa' x 'Ropta B 1178' & $\mathrm{HOL}$ \\
\hline 11 & CANELLE & EPAMIG & Not available & FRA \\
\hline 12 & CATUCHA & EPAMIG & '2CRI 1149-178’x ‘C-999-263-70’ & BRA \\
\hline 13 & CHIPIE & EPAMIG & 'Pilgrim' x ('Saturna' x Pentland Dell') & FRA \\
\hline 14 & COLORADO & EPAMIG & 'Torridon' x ('Desiree' x 'Pentland Dell') & FRA \\
\hline 15 & CUPIDO & Pirassu & 'W 72-22-496’ x 'Estima' & HOL \\
\hline 16 & EDEN & EPAMIG & ‘Eole'x 'Pentland Dell' & FRA \\
\hline 17 & EMERAUDE & EPAMIG & 'Estima x 'INRA 75.36.45’ & FRA \\
\hline 18 & EOLE & EPAMIG & 'Ukama' x 'INRA 74.38.12' & FRA \\
\hline 19 & FIANNA & Pirassu & ‘4062-660’ x ‘AM 66-42 & HOL \\
\hline 20 & FLORICE & EPAMIG & 'Fanette' X 'INRA' 72.68 .5 & FRA \\
\hline 21 & FONTANE & EPAMIG & 'Agria' x 'AR 76-34-3’ & HOL \\
\hline 22 & GOURMANDINE & EPAMIG & 'Charlote' x 'Estima' & FRA \\
\hline 23 & GREDINE & EPAMIG & Not available & FRA \\
\hline 24 & HPC-7B & Pirassu & S. chacoense x S. phureja & - \\
\hline 25 & ITARARÉ & Pirassu & ‘Arensa’x 'Turma' x 'Leo’ & BRA \\
\hline 26 & LADY ROSETTA & Pirassu & 'Cardinal' x 'SVP(VTN)62-33-3' & HOL \\
\hline 27 & MELODIE & EPAMIG & ‘VE 74-45’ x ‘W 72-22-496’ & HOL \\
\hline 28 & MONALISA & Pirassu & 'Bierma A 1-287’ x 'Colmo' & HOL \\
\hline 29 & MONALISA & EPAMIG & ‘Bierma A 1-287’ x ‘Colmo’ & HOL \\
\hline 30 & MONDIAL & Pirassu & ‘Spunta’ x ‘VE 66-295’ & HOL \\
\hline 31 & NATURELLA & EPAMIG & 'Sirco' X 'Pentland Squire' & FRA \\
\hline 32 & OPALINE & EPAMIG & Non available & FRA \\
\hline 33 & PANDA & Pirassu & 'UP 0.351/17’ x 'W 6858/8' & BRD \\
\hline 34 & PIRASSU & Pirassu & Mutant of 'Lady Rosetta' & HOL \\
\hline 35 & SANTÉ & Pirassu & 'Y 66-13-636' x 'AM 66-42' & HOL \\
\hline 36 & SOLÉIA & EPAMIG & Not available & FRA \\
\hline 37 & SPUNTA & Pirassu & 'BEA'x 'USDA 96-56’ & HOL \\
\hline 38 & VOYAGER & EPAMIG & 'RZ 85-238'x 'Obelix’' & $\mathrm{HOL}$ \\
\hline
\end{tabular}

${ }^{1}$ Pirassu -Vargem Grande do Sul, SP; EPAMIG - Empresa de Pesquisa Agropecuária de Minas Gerais, MG.; ${ }^{2}$ Hutton et al. (2009); Miranda Filho et al. (1986); Miranda Filho (1991); Plant de Pomme de Terre (2009); Meijer (2009); Nivap (2009); Pádua (2009).

potato cultivars with 21 SSR primers, Ghislain et al. (2006), with the PIC values ranging from 0.0 to 0.67 in the evaluation of 170 potato genotypes with 22 SSR loci, and Mathias et al. (2007), with PIC values ranging from
0.42 to 0.90 for a total of 71 genotypes of potato and 21 SSR loci. Fu et al. (2009), however, observed much lower PIC values, ranging from 0.01 to 0.49 , when assessing 114 Canadian and 55 exotic potato accessions with $36 \mathrm{SSR}$ loci. Therefore, the information level depends on the set of primers used and the material evaluated. These authors concluded that the Canadian accessions have a narrow genetic basis, while the exotic accessions showed greater 
Table 2. Potato (Solanum tuberosum) primers ${ }^{1}$ used in this study. including the number of alleles per locus. the annealing temperature $\left(\mathrm{T}^{\circ} \mathrm{C}\right)$. the size in bp and the polymorphism information content (PIC) per locus (iniciadores específicos para a batata ${ }^{1}$ (Solanum tuberosum). utilizados neste estudo. incluindo o número de alelos por loco. a temperatura de anelamento $\left(\mathrm{T}^{\circ} \mathrm{C}\right)$. o tamanho em pb. e o conteúdo de informação de polimorfismo (PIC) por loco). Piracicaba. USP-ESALQ. 2009.

\begin{tabular}{|c|c|c|c|c|c|}
\hline Locus & Sequence $\left(5^{\prime} \rightarrow 3^{\prime}\right)$ & $\mathbf{N}^{\circ}$ alleles & $\mathrm{T}^{\circ} \mathrm{C}$ & Size pb & PIC \\
\hline STM0019a & $\begin{array}{l}\text { F: AATAGGTGTACTGACTCTCAATG } \\
\text { R: TTGAAGTAAAAGTCCTAGTATGTG }\end{array}$ & 12 & 54.3 & $160-280$ & 0.8583 \\
\hline STM0037 & $\begin{array}{l}\text { F: AATTTAACTTAGAAGATTAGTCTC } \\
\text { R: ATTTGGTTGGGTATGATA }\end{array}$ & 6 & 56.1 & $70-100$ & 0.7149 \\
\hline STM1049 & $\begin{array}{l}\text { F: CTACCAGTTTGTTGATTGTGGTG } \\
\text { R: AGGGACTTTAATTTGTTGGACG }\end{array}$ & 2 & 61.6 & $190-200$ & 0.6073 \\
\hline STM1053 & $\begin{array}{l}\text { F: TCTCCCCATCTTAATGTTTC } \\
\text { R: CAACACAGCATSCAGATCATC }\end{array}$ & 2 & 60 & $180-190$ & 0.1264 \\
\hline STM1104 & $\begin{array}{l}\text { F: TGATTCTCTTGCCTACTGTAATCG } \\
\text { R: CAAAGTGGTGTGAAGCTGTGA }\end{array}$ & 2 & 60 & $170-180$ & 0.3732 \\
\hline STM1106 & $\begin{array}{l}\text { F: TCCAGCTGATTGGTTAGGTTG } \\
\text { R: ATGCGAATCTACTCGTCATGG }\end{array}$ & 4 & 60 & $150-170$ & 0.5554 \\
\hline STM2013 & $\begin{array}{l}\text { F: TTCGGAATTACCCTCTGCC } \\
\text { R: AAAAAAAGAACGCGCACG }\end{array}$ & 3 & 60 & $145-160$ & 0.5678 \\
\hline STM2022 & $\begin{array}{l}\text { F: GCGTCAGCGATTTCAGTACTA } \\
\text { R: TTCAGTCAACTCCTGTTGCG }\end{array}$ & 6 & 64 & $170-230$ & 0.4301 \\
\hline STM3012 & $\begin{array}{l}\text { F: CAACTCAAACCAGAAGGCAAA } \\
\text { R: GAGAAATGGGCACAAAAAACA }\end{array}$ & 3 & 66 & $170-210$ & 0.5039 \\
\hline STPoAc58 & $\begin{array}{l}\text { F: TTGATGAAAGGAATGCAGCTTGTG } \\
\text { R: ACGTTAAAGAAGTGAGAGTACGAC }\end{array}$ & 6 & 63 & $240-285$ & 0.6997 \\
\hline
\end{tabular}

${ }^{1}$ Ghislain et al. (2006).

variability.

The Jaccard's similarity coefficient ranged from 0.41 to 0.93 (Figure 1), showing a significant genetic variability for the commercial varieties assessed in this study, higher than the 16 Brazilian cultivars evaluated by Rocha (2008), where the Jaccard's coefficient ranged from 0.57 to 0.73 . Braun \& Wenzel (2004) found a total of 128 SSR bands and $98.4 \%$ polymorphism when assessing 47 genotypes of the potato breeding program in Germany, with the similarity coefficient of Nei \& $\mathrm{Li}(1979)$ ranging from 0.57 to 0.79 , showing less variability than the cultivars used in this study. Similar results to our study were obtained by Barandalla et al. (2006) in the evaluation of 41 cultivars of the Tenerife Island using 19 SSR loci, with the Jaccard's coefficient ranging from 0.57 to 1.00 .

The 38 cultivars were classified in three groups, according to the Bootstrap criterion, in the cluster analysis (Figure 1 ), showing a cophenetic value of
0.7423 . The first group, with a $53 \%$ confidence degree, was composed of all the varieties except for Lady Rosetta and HPC-7B varieties. The second group included Lady Rosetta variety, with a $53 \%$ degree of confidence obtained by the Bootstrap method, while the third group classified the HPC-7B variety, with $100 \%$ reliability. Within the first group, the data suggests the presence of a duplicate for the cultivars Atlantic (Canada) and Atlantic (Chile) from Pirassu collection, as expected, since they are same variety, but originated from different places. They presented $93 \%$ similarity by Jaccard's coefficient and a confidence degree of $97 \%$. However, the Atlantic cultivar from EPAMIG collection, was not genetically identical to these two accessions. The Atlantic cultivar is also known to be originated from different parents (Pepita x Desireé) (Hutten et al., 2009), which could be an explanation.

Varieties Colorado and Agata (EPAMIG) also showed high similarity with approximately $91 \%$ similarity by the Jaccard's coefficient and a $67 \%$ confidence degree. Rocha (2008) also observed high similarity $(69 \%$ by the coefficient of Jaccard) between these two cultivars (Agata and Colorado). However, these cultivars do not have parents in common (Table 1), and also do not have similar morphological and horticultural traits. It is interesting to emphasize that cultivar Agata, from the two collections (EPAMIG and Pirassu), were genetically distinct, although both of them are part of the large group (group I). Cultivar Agata (Pirassu) was closer to Mondial, with about $75 \%$ similarity and $47 \%$ reliability. The same result was found for cultivar Monalisa from both collections, both of them with the same genealogies. Further SSR analyses were conducted to confirm these results, and therefore we concluded that these cultivars could not be considered genetically identical. Possible explanations are the occurrence of somatic mutations at the various 


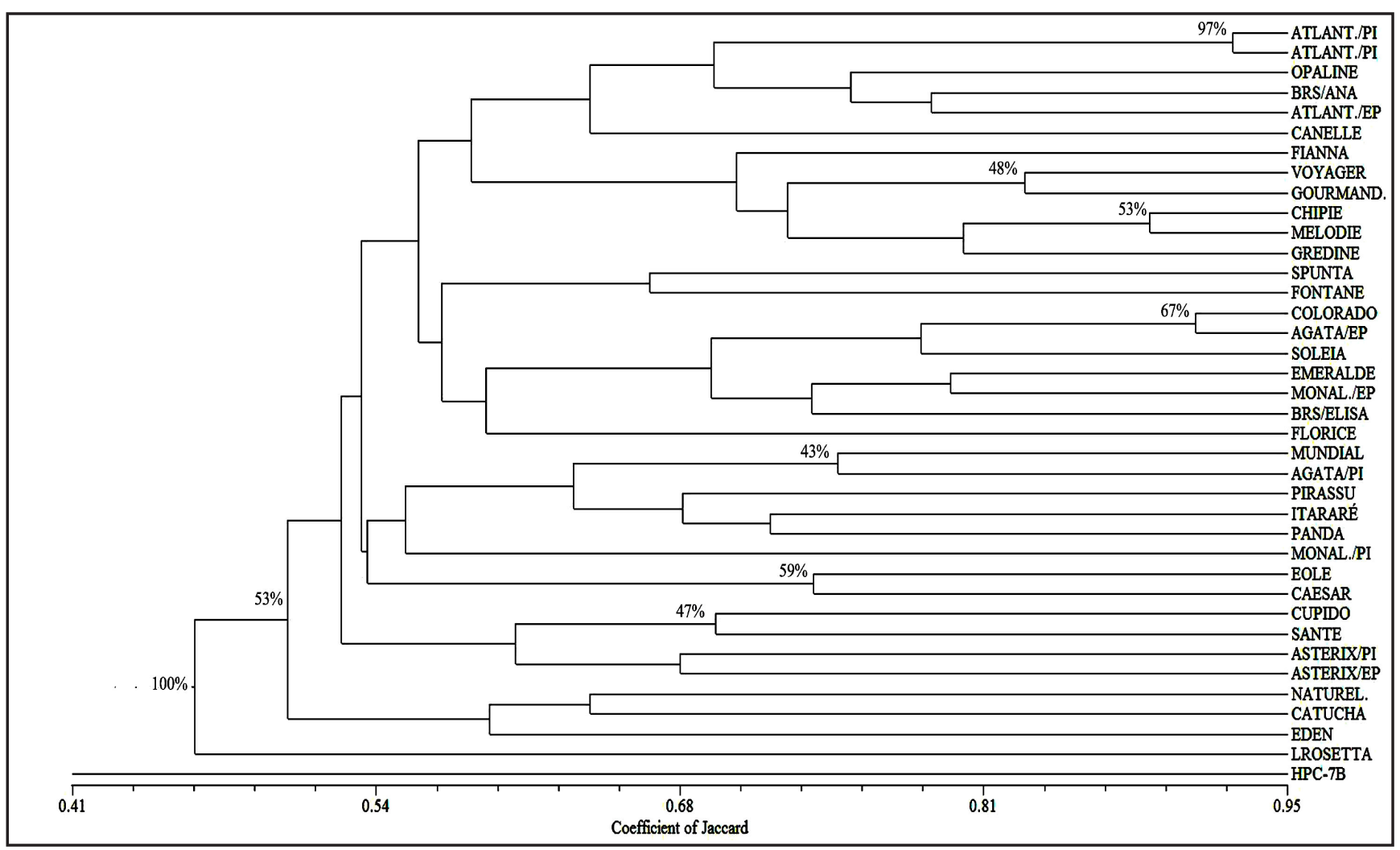

Figure 1. Dendrogram obtained from the Jaccard's similarity coefficient, the UPGMA cluster method and confidence degree using the Bootstrap method for 38 cultivars of potato (Solanum tuberosum) (dendrograma obtido a partir do coeficiente de similaridade de Jaccard, pelo método aglomerativo UPGMA e grau de confiança pelo método Bootstrap, para 38 cultivares de batata (Solanum tuberosum)). Piracicaba, USP-ESALQ, 2009.

phases of multiplication since its origin in Brazil.

Cultivars Chipie and Melodie, both from EPAMIG collection, were also very similar, with about $90 \%$ similarity and $53 \%$ reliability in this grouping, followed by Voyager and cultivar Gourmandine (EPAMIG) with 48\% reliability, and cultivars Eole and Caesar (EPAMIG), with a $59 \%$ confidence degree. These two cultivars are similar in relation to the tuber traits, which are oval, large, with a moderately smooth yellow skin and shallow eyes. Varieties Cupido and Santé (Pirassu) were also similar, with approximately $70 \%$ similarity, but with a degree of reliability of $47 \%$. It is worth considering that there are similarities found in the tubers traits of these two cultivars, which are large, oval to round-oval and uniform, with a smooth and yellow skin and light yellow flesh.

Variety HPC-7B (Pirassu), derived from the cross between Solanum phureja and $S$. chacoense, was the most divergent accession from this collection, which was already expected considering it to be a diploid and originated from two different species, and was followed by Lady Rosetta (Pirassu), originated in Holland from the crosses 'Cardinal' $x$ 'SVP(VTN)62-33-3'. HPC-7B cultivar is used mostly in plant breeding programs as a parent in crosses, as it shows high resistance to late blight (Phytophtora infestans) and nematodes (Silva et al., 2010).

The polymorphism levels presented in this study are high, considering that in the analyses each allele is a unique character and, as potato is a tetraploid species, each individual may present from one to four different alleles in one locus. This contributes to a high level of genetic diversity. Associated with the high reproducibility of the SSR markers, the results obtained in this study support the use of these markers as an important tool in the molecular characterization of potato varieties in germplasm banks, in the identification of duplicates, in the correct identification of cultivars and of genetically divergent potential parents to be used in breeding programs.

\section{ACKNOWLEDGMENTS}

To Eng ${ }^{\circ}$ Agr $^{\circ}$ Pedro Candido Rytsi Hayashi from Pirassu and the researcher Dr. Joaquim Gonçalves de Pádua from EPAMIG for providing the genetic material. To CAPES for the scholarship granted.

\section{REFERENCES}

AGRIANUAL. 2009. Batata: alternativa nutricional em tempos de alimentos caros. In: AGRIANUAL 2009: anuário da agricultura brasileira. São Paulo: FNP Consultoria \& Comércio. p. 210-207.

BARANDALLA L; RUIZ DE GALARRETA JI; RIOS D; RITTER E. 2006. Molecular analysis of local potato cultivars from Tenerife Island using microsatellite markers. Euphytica 152: 283-291.

BASSAM BJ; CAETANO-ANOLLÉS G; GRESSHOFF PM. 1991. Fast and sensitive silver staining of DNA in polyacrylamide gels. Analytical Biochemistry 196: 80-83.

BORÉM A; CAIXETA ET. 2006. Marcadores moleculares. Viçosa: UFV. 374p. 
BRAUN A; WENZEL G. 2004. Molecular analysis of genetic variation in potato (Solanum tuberosum L.). I. German cultivars and advanced clones. Potato Research 47: 81-92.

BRAUN A; SCHULLEHNER K; WENZEL G. 2004. Molecular analysis of genetic variation in potato (Solanum tuberosum L.). II. International cultivar spectrum. Potato Research 47: 93-100.

CIP. 2011. Centro Internacional de La Papa. Potato - global production. Available in http://www. cipotato.org. Accessed in January 4, 2011.

CHIMOTE VP; CHAKRABARTI SK; PATTANAYAK D; NAIK PS. 2004. Semiautomated simple sequence repeat analysis reveals narrow genetic base in Indian potato cultivars. Biologia Plantarum 48: 517-522.

COELHO ASG. 2001. BOOD v.2.0 - Avaliação de dendrogramas baseados em estimativas de distâncias/similaridades genéticas através do procedimento de bootstrap. Goiânia: UFG.

FAO, 2008. Food and Agriculture Organization. International year of potato. Available in http://www.potato2008.or/en/ world/index. Accessed in Dec 20, 2008.

FERREIRA ME; GRATTAPAGLIA D. 1998. Introdução ao uso de marcadores moleculares em análise genética. Brasília: EMBRAPA/ CENARGEN. 220p.

FU YB; PETERSON GW; RICHARDS KW; TARN TR; PERCY JE. 2009. Genetic diversity of Canadian and exotic potato germplasm revealed by simple sequence repeat markers. American Journal of Potato Research 86: 38-48.

GHISLAIN M; ANDRADE D; RODRÍGUEZ F; HIJMANS RJ; SPOONER DM. 2006. Genetic analysis of the cultivated potato Solanum tuberosum L. Phureja group using RAPDs and nuclear SSRs. Theoretical and Applied Genetics 113: 1515-1527.
HUTTEN R; BERLOO RV; FINKERS R. 2009 Potato pedigree database. Available in http:// www.plantbreeding.wur.nl/potatopedigree. Accessed in Jan 03, 2011.

IBGE. 2009. Instituto Brasileiro de Geografia e Estatística. Levantamento sistemático da produção agrícola. Disponível em http://www. ibge.gov.br/home/estatistica/indicadores/ agropecuaria/ispa/ispa_200902_1.shtm. Acessado em 28 de fevereiro de 2009 .

ISPIZÚA VN; GUMA IR; FEINGOLD S; CLAUSEN AM. 2007. Genetic diversity of potato landraces from northwestern Argentina assessed with simple sequence repeats (SSRs). Genetic Resources and Crop Evolution 54: 1833-1848.

MATHIAS M; SAGREDO B; KALAZICH J. 2007. Uso de marcadores SSR para identificación de germoplasma de papa en el programa de mejoramiento de INIA de Chile. Agricultura Técnica 67: 3-15.

MEIJER. 2009. Cupido. Available in http://www. meijer-potato.com/htm/uk/rassen/cupido. htm. Accessed in Jan 25, 2009.

MILBOURNE D; MEYER RC; BRADSHAW JE; BAIRD E; BONAR N; PROVAN J; POWELL W; WAUGH R. 1997. Comparison of PCR-based marker systems for the analysis of genetic relationships in cultivated potato. Molecular Breeding 3: 127-136.

MIRANDA FILHO HS. 1991. Novo cultivar de batata IAC Aracy ruiva. Campinas: IAC (catálogo de variedades).

MIRANDA FILHO HS; RAMOS VJ; GRANJA NP; DIAS JACS; COELHO SMB; TEIXEIRA PRM; SIQUEIRA WJ. 1986. Batata Itararé (IAC-5986). O Agronômico 38: 119-121.

NEI M; LI WH. 1979. Mathematical module for studying genetic variation in terms of restriction endonucleases. Proceedings of the National Academy of Sciences USA 6: 5269-5273.
NIVAP. 2009. HOLLAND - NETHERLANDS Potato Consultative Foundation. Catálogo das variedades de batata dos países baixos, 2007. Available in http://www.nivaa.nl/pt/a_batata/ catalogo_holanda_de_variedades_de_batata. Accessed in Mar 30, 2009.

NORERO N; MALLEVILLE J; HUARTE M; FEINGOLD S. 2002. Cost efficient potato (Solanum tuberosum L.) cultivar identification by microsatellite amplification. Potato Research 45: 131-138.

PÁDUAJG. 2009. Cultivares de batata. Available in www.prointegrada.ufv.br/batata/doc/ palestras/cultivares_batata.pdf. Accessed in Mar 23, 2009.

PLANT DE POMME DE TERRE. 2009. Les principales varietés produites en France. Available in http://www.plantdepommedeterre. org/pages/mainvar.php. Accessed in Mar 30, 2009.

ROCHA EA. 2008. Caracterização molecular de cultivares de batata (Solanum tuberosum L.) utilizando marcadores RAPD e SSR. Lavras: UFLA. $113 \mathrm{p}$.

ROHLF FJ. 1992. NTSYS-PC: numerical taxonomy and multivariate analysis system version 2.02. New York: State University of New York, Stony Brook.

SILVA AR; SANTOS JM; HAYASHI PCR; HAYASHI E. 2010. Reação de clones e cultivares de batata avaliados em casa de vegetação a Meloidogyne incognita, $M$. javanica e $M$. mayaguensis e in vitro a $M$. javanica. Nematologia Brasileira 34: 48-55.

SIQUEIRA MVBM; QUEIROZ-SILVA JR; BRESSAN EA; BORGES A; PEREIRA KJC; PINTO JG; VEASEY EA. 2009. Genetic characterization of cassava (Manihot esculenta) landraces in Brazil assessed with simple sequence repeats. Genetics and Molecular Biology 32: 104-110. 